\title{
Research on the Influence of Household Operating Income in Heilongjiang from Agricultural Production Material Investment
}

\author{
Zhang Dehua \\ Institute of Finance \\ Harbin University of Commerce \\ Harbin, China, 150028 \\ e-mail: zdh19841027@163.com
}

\begin{abstract}
Heilongjiang, as the major grain producing province, makes outstanding contributions to grain. Farmers mainly engage in food production and their household operating income mainly depends on food income. Therefore, to protect farmers' food income in Heilongjiang has become the key problem of ensuring food security. Through correlation analysis, multiple linear regression and path analysis, the paper using the relevant data from 1995 to 2013 analyzes the relationship between agricultural production material investment and farmers' household operating income in Heilongjiang, analyzes its direct and indirect influences and ultimately comes to the conclusion that production material has a positive impact on farmers' household operating income, but the difference of influencing degree is large with different production material investment.
\end{abstract}

Keywords- production material investment; farmers; household operating income; direct influence; indirect influence

\section{MULTIPLE LINEAR REGRESSIONS}

The purpose of the study is to analyze influencing factors of farmers' income and gets its main reason. So the paper analyzes the selected data using multiple linear regression models and specific form of the model is as follows $^{[1]}$ :

$$
Y=\mathrm{C}+\sum_{i=1}^{n} \beta_{i} X_{i}+\varepsilon
$$

$\mathrm{Y}$ represents the farmers' income, $\mathrm{C}$ is a constant term, $\beta \mathrm{i}$ is regression coefficients of corresponding variable, $\mathrm{Xi}$ is the corresponding variable, $\varepsilon$ is a random disturbance, the range of $n$ is between 1 and 21 .

\section{MODEL INDICATOR SELECTION AND DIRECTION FORECAST}

Farmers' household operating income in Heilongjiang consists of the primary industry, secondary industry and tertiary industry. Among them, the primary industry lies in the dominated position and its proportion on household operating income is more than $95 \%$. Also, the proportion of agricultural income is more than $90 \%$ in the primary industry. So in order to analyze household operating income in Heilongjiang, the paper mainly studies the influencing factors of agricultural income. The related influencing factors with agricultural income mainly include scale factors, technological factors, human resources factors, infrastructure factors, market factors and planting structure factors. Coupled with urbanization factors, specific indicators of household operating income in Heilongjiang are as follows: $X_{1}$ is per capita sown areas of crops, $\mathrm{X}_{2}$ is the proportion of junior higher education on average hundred labors, $\mathrm{X}_{3}$ is the number of rural labor force, $\mathrm{X}_{4}$ is average amount of chemical fertilizer, $\mathrm{X}_{5}$ is average machinery gross power, $X_{6}$ is the effective irrigation areas, $\mathrm{X}_{7}$ is the proportion of grain sown areas, $\mathrm{X}_{8}$ is the proportion of agricultural output, $\mathrm{X}_{9}$ is agricultural production material price index, $\mathrm{X}_{10}$ is the agricultural products price index, $\mathrm{X}_{11}$ is the proportion of urban population and $\mathrm{X}_{12}$ is the proportion of labors in primary industry ${ }^{[3-8]}$. The direction forecast on influencing farmers' household operating income in Heilongjiang form each factor is as follows:

TABLE I. ASSUMING DIRECTION OF MODEL VARIABLES

\begin{tabular}{cc}
\hline variables & $\begin{array}{c}\text { assuming } \\
\text { direction }\end{array}$ \\
\hline $\begin{array}{c}\text { per capita sown areas of crops }\left(\mathrm{X}_{1}\right) \\
\text { proportion of junior higher education on } \\
\text { average hundred labors }\left(\mathrm{X}_{2}\right)\end{array}$ & + \\
the number of rural labor force $\left(\mathrm{X}_{3}\right)$ & + \\
$\begin{array}{c}\text { average amount of chemical fertilizer } \\
\left(\mathrm{X}_{4}\right)\end{array}$ & + \\
$\begin{array}{c}\text { average machinery gross power }\left(\mathrm{X}_{5}\right) \\
\text { the effective irrigation areas }\left(\mathrm{X}_{6}\right)\end{array}$ & + \\
the proportion of grain sown areas \\
$\quad\left(\mathrm{X}_{7}\right)$
\end{tabular}$\quad+$




\section{MODEL DATA SELECTION AND RESULT ANALYSIS}

The paper chooses influencing factors of per capita net income in Heilongjiang from 1993 to 2010, together with the data of household operating income from 1993 to 2010 Using SPSS, the paper analyzes relevant data through correlation analysis, multiple linear regression and path analysis and arrives at the following conclusions:

TABLE II. CORRELATIONS (1)

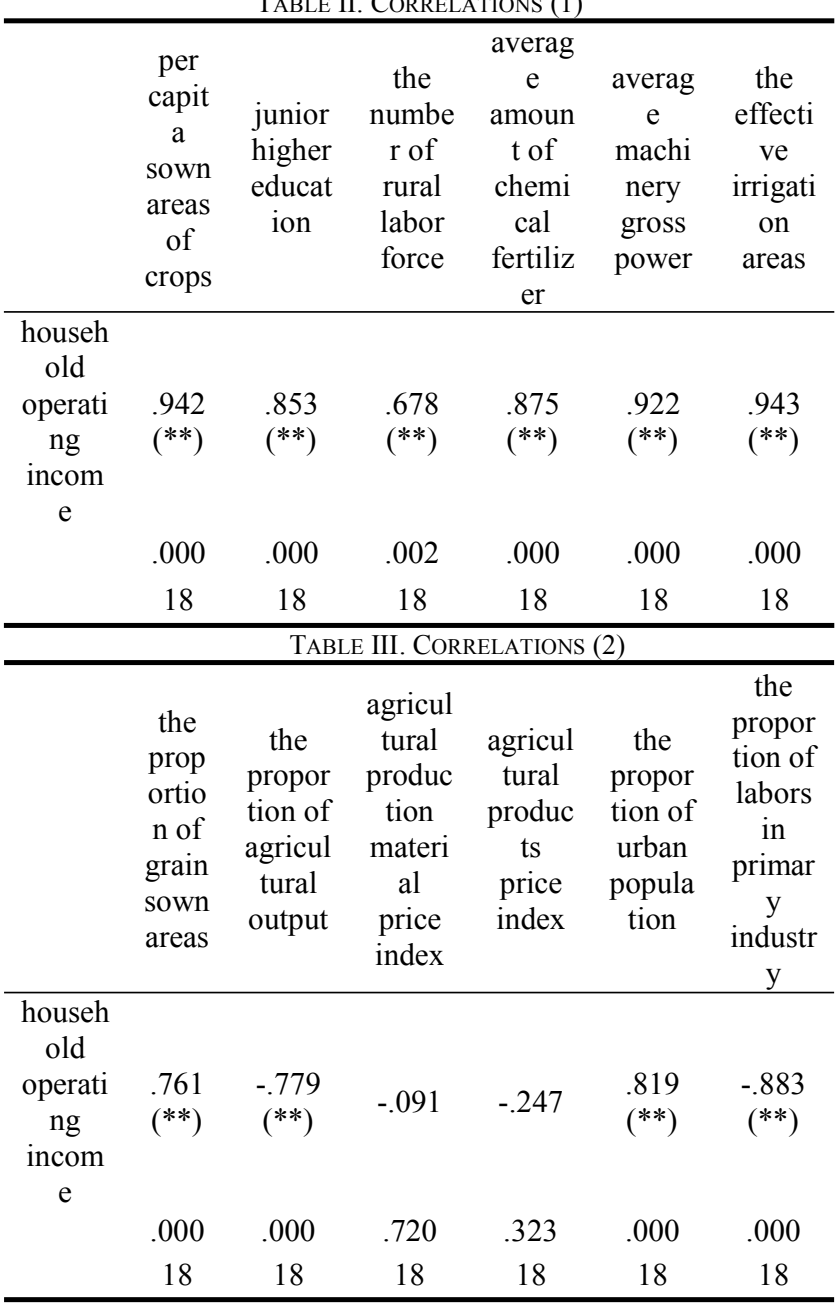

** Correlation is significant at the 0.01 level (2-tailed).

* Correlation is significant at the 0.05 level (2-tailed).

From the result, we can see that household operating income in Heilongjiang has a positive correlation with $\mathrm{X}_{1}$ per capita sown areas of crops, $\mathrm{X}_{2}$ the proportion of junior higher education on average hundred labors, $X_{3}$ the number of rural labor force, $\mathrm{X}_{4}$ average amount of chemical fertilizer, $\mathrm{X}_{5}$ average machinery gross power, $\mathrm{X}_{6}$ the effective irrigation areas, $X_{7}$ the proportion of grain sown areas and $\mathrm{X}_{11}$ the proportion of urban population. It has a negative correlation with $\mathrm{X}_{8}$ the proportion of agricultural output, $\mathrm{X}_{9}$ agricultural production material price index, $\mathrm{X}_{10}$ agricultural products price index and $\mathrm{X}_{12}$ the proportion of labors in primary industry. Compared with the expected direction, only $\mathrm{X}_{10}$ agricultural products price index is contrast with the prediction and other factors with the forecast keep the same basically. However, the significance of $\mathrm{X}_{10}$ agricultural products price index is not very obvious and its sig. value 0.720 is much greater than 0.05 , indicating that its correlation coefficient is not credible.

\begin{tabular}{ccc}
\multicolumn{3}{c}{ TABLE IV. VARIABLES ENTERED/REMOVED (A) } \\
\hline Model & Variables Entered & Variables Removed \\
\hline 1 & $\begin{array}{c}\text { the effective } \\
\text { irrigation areas } \\
\text { the proportion of } \\
\text { urban population } \\
\text { proportion of labors } \\
\text { in primary industry } \\
\text { average machinery } \\
\text { gross power } \\
\text { average amount of } \\
\text { chemical fertilizer }\end{array}$ &. \\
5 & &. \\
\hline
\end{tabular}

a Dependent Variable: household operating income

As we can see from the regression analysis results, five variable indicators are kept among twelve indicators, which are $\mathrm{X}_{4}$ average amount of chemical fertilizer, $\mathrm{X}_{5}$ average machinery gross power, $\mathrm{X}_{6}$ the effective irrigation areas, $\mathrm{X}_{11}$ the proportion of urban population and $\mathrm{X}_{12}$ the proportion of labors in primary industry.

TABLE V. MODEL SUMMARIES

\begin{tabular}{ccccc}
\hline $\begin{array}{c}\mathrm{M} \\
\text { od } \\
\mathrm{el}\end{array}$ & $\mathrm{R}$ & R Square & $\begin{array}{c}\text { Adjusted R } \\
\text { Square }\end{array}$ & $\begin{array}{c}\text { Std. Error } \\
\text { of the } \\
\text { Estimate }\end{array}$ \\
\hline 1 & $.943(\mathrm{a})$ & .890 & .883 & 257.87013 \\
2 & $.980(\mathrm{~b})$ & .960 & .955 & 159.76128 \\
3 & $.986(\mathrm{c})$ & .972 & .966 & 138.93508 \\
4 & $.990(\mathrm{~d})$ & .980 & .974 & 120.37705 \\
5 & $.995(\mathrm{e})$ & .989 & .985 & 92.15928 \\
\hline
\end{tabular}

$\mathrm{X}_{6}$ the effective irrigation areas enters the model first and its determination coefficient is 0.967 which indicates that $\mathrm{X}_{6}$ the effective irrigation areas can explain the changes of $89 \%$ and it is the most important influencing factor. The second variable is $\mathrm{X}_{11}$ the proportion of urban population and its determination coefficient is 0.960 which increases by 0.70 . The third variable is $X_{12}$ the proportion of labors in primary industry and its determination coefficient is 0.972 which increases by 0.12 . The fourth variable is $\mathrm{X}_{5}$ average machinery gross power and its determination coefficient is 0.980 which increases by 0.08 , the fifth variable is $\mathrm{X}_{4}$ average amount of chemical fertilizer and its determination coefficient is 0.989 which increases by 0.09 . The sequence of the variables entering the model represents their significance in this model. The more forward the order is, the more important its significance is. TABLE VI. ANOVA (F)

\begin{tabular}{cccccc}
\hline & $\begin{array}{c}\text { Sum of } \\
\text { Squares }\end{array}$ & df & $\begin{array}{c}\text { Mean } \\
\text { Square }\end{array}$ & F & Sig. \\
\hline Regress & 9556310. & 5 & 191126 & 225.031 & .000 \\
ion & 701 & & 2.140 & & \\
Residua & 101920.0 & 13 & 8493.33 & & \\
1 & 01 & 13 & & \\
Total & 9658230. & \multirow{2}{*}{18} & & & \\
\hline
\end{tabular}


TABLE VII COEFFICIENTS (A)

\begin{tabular}{|c|c|c|c|c|c|}
\hline & \multicolumn{2}{|c|}{$\begin{array}{l}\text { Unstandardize } \\
\text { d Coefficients }\end{array}$} & $\begin{array}{l}\text { Standar } \\
\text { dized } \\
\text { Coeffici } \\
\text { ents } \\
\end{array}$ & \multirow[t]{2}{*}{$\mathrm{t}$} & \multirow[t]{2}{*}{ Sig. } \\
\hline & B & $\begin{array}{l}\text { Std. } \\
\text { Error }\end{array}$ & Beta & & \\
\hline (Constant) & $\begin{array}{c}- \\
831.1 \\
33\end{array}$ & $\begin{array}{c}2313 . \\
447\end{array}$ & & -.359 & .726 \\
\hline $\begin{array}{l}\text { the effective } \\
\text { irrigation areas }\end{array}$ & .985 & .164 & 1.050 & 6.015 & .000 \\
\hline $\begin{array}{c}\text { the proportion } \\
\text { of urban } \\
\text { population }\end{array}$ & $\begin{array}{c}177.0 \\
05\end{array}$ & $\begin{array}{c}27.00 \\
5\end{array}$ & .288 & 6.555 & .000 \\
\hline $\begin{array}{c}\text { the proportion } \\
\text { of labors in } \\
\text { primary } \\
\text { industry }\end{array}$ & $\begin{array}{c}- \\
91.21 \\
0\end{array}$ & $\begin{array}{c}16.85 \\
4\end{array}$ & -.677 & 5.412 & .000 \\
\hline $\begin{array}{c}\text { average } \\
\text { machinery } \\
\text { gross power }\end{array}$ & $\begin{array}{c}- \\
2004 . \\
043\end{array}$ & $\begin{array}{c}487.1 \\
80\end{array}$ & -1.103 & 4. & .001 \\
\hline $\begin{array}{l}\text { amount of } \\
\text { chemical } \\
\text { fertilizer }\end{array}$ & $\begin{array}{c}16.52 \\
8\end{array}$ & 5.180 & .207 & 3.191 & .008 \\
\hline
\end{tabular}

a Dependent Variable: household operating income

Through regression analysis, we can see that $\mathrm{R}^{2}$ is 0.989 as the final model and $\mathrm{R}^{2}$ is 0.985 after adjustment, also is much more than 0.8 , indicating that the fitting effect of model is great. $F=225.031$ and sig. $=0.000$ $<0.05$, which indicates that the model has passed $F$ test and rejects the null hypothesis. There exists significant linear relationship between independent variables in the model and per capita household operating income (see Tab.VIII). The main factors of influencing per capita household operating income in Heilongjiang are $\mathrm{X}_{6}$ the effective irrigation areas, $\mathrm{X}_{11}$ the proportion of urban population, $\mathrm{X}_{12}$ the proportion of labors in primary industry, $\mathrm{X}_{5}$ average machinery gross power and $\mathrm{X}_{4}$ average amount of chemical fertilizer. They pass $t$ test at $5 \%$ significance level and their sig. value is $0.000,0.000$, $0.000,0.001$ and 0.008 respectively which is less than $5 \%$. Their coefficients are $0.985,177.005,-91.210,-2004.043$ and 16.528 respectively. Finally, we get the decision equation of per capita farmers' household operating income in Heilongjiang:

$Y=-831.133+0.985 X_{6}+177.005 X_{11}$

$-91.210 X_{12}-2004.043 X_{5}+16.528 X_{4}+\varepsilon$

Through path analysis, we can see that direct path coefficient of $\mathrm{X}_{6}$ the effective irrigation areas is 1.050 (see Tab. IX). The indirect path coefficient is $0.189,0.607$, 1.103 , and 0.207 conducted by $\mathrm{X}_{11}$ the proportion of urban population, $\mathrm{X}_{12}$ the proportion of labors in primary industry, $\mathrm{X}_{5}$ average machinery gross power and $\mathrm{X}_{4}$ average amount of chemical fertilizer.

The direct path coefficient of $\mathrm{X}_{11}$ the proportion of urban population is 0.288 (see Tab. IX). The indirect path coefficient is $0.689,0.379,-0.683$ and 0.146 conducted by $\mathrm{X}_{6}$ the effective irrigation areas, $\mathrm{X}_{12}$ the proportion of labors in primary industry, $\mathrm{X}_{5}$ average machinery gross power and $\mathrm{X}_{4}$ average amount of chemical fertilizer.

The direct path coefficient of $\mathrm{X}_{12}$ the proportion of labors in primary industry is -0.667 (see Tab. IX). The indirect path coefficient is $-0.941,-0.161,1.502$ and 0.156 conducted by $\mathrm{X}_{6}$ the effective irrigation areas, $\mathrm{X}_{11}$ the proportion of urban population, $\mathrm{X}_{5}$ average machinery gross power and $\mathrm{X}_{4}$ average amount of chemical fertilizer.

The direct path coefficient of $\mathrm{X}_{5}$ average machinery gross power is -1.103 (see Tab. IX). The indirect path coefficient is $1.026,0.178,0.646$ and 0.175 conducted by $\mathrm{X}_{6}$ the effective irrigation areas, $\mathrm{X}_{12}$ the proportion of labors in primary industry, $\mathrm{X}_{11}$ the proportion of urban population and $\mathrm{X}_{4}$ average amount of chemical fertilizer.

The direct path coefficient of $\mathrm{X}_{4}$ average amount of chemical fertilizer is 0.207 (see Tab. IX). The indirect path coefficient is $0.887,0.202,0.510$ and -0.932 conducted by $\mathrm{X}_{6}$ the effective irrigation areas, $\mathrm{X}_{11}$ the proportion of urban population, $\mathrm{X}_{12}$ the proportion of labors in primary industry and $\mathrm{X}_{5}$ average machinery gross power. TABLE VIII. CORRELATIONS

\begin{tabular}{|c|c|c|c|c|c|}
\hline & $\begin{array}{l}\text { the } \\
\text { effecti } \\
\text { ve } \\
\text { irrigati } \\
\text { on } \\
\text { areas }\end{array}$ & $\begin{array}{l}\text { the } \\
\text { prop } \\
\text { ortio } \\
\mathrm{n} \text { of } \\
\text { urba } \\
\mathrm{n} \\
\text { popu } \\
\text { latio } \\
\mathrm{n}\end{array}$ & $\begin{array}{l}\text { the } \\
\text { proport } \\
\text { ion of } \\
\text { labors } \\
\text { in } \\
\text { primary } \\
\text { industr } \\
y\end{array}$ & $\begin{array}{l}\text { average } \\
\text { machin } \\
\text { ery } \\
\text { gross } \\
\text { power }\end{array}$ & $\begin{array}{l}\text { avera } \\
\text { ge } \\
\text { amou } \\
\text { nt of } \\
\text { chemi } \\
\text { cal } \\
\text { fertili } \\
\text { zer }\end{array}$ \\
\hline $\begin{array}{c}\text { th effective } \\
\text { irrigation } \\
\text { areas }\end{array}$ & 1 & $\begin{array}{l}656 \\
(* *)\end{array}$ & $\begin{array}{c}-.896 \\
(* *)\end{array}$ & $\begin{array}{l}.977 \\
(* *)\end{array}$ & $\begin{array}{l}.845 \\
(* *)\end{array}$ \\
\hline Sig. & . & .003 & .000 & .000 & .000 \\
\hline $\begin{array}{l}\mathrm{N} \\
\text { the }\end{array}$ & 18 & 18 & 18 & 18 & 18 \\
\hline $\begin{array}{c}\text { proportion of } \\
\text { urban } \\
\text { population }\end{array}$ & $\begin{array}{l}.656 \\
(* *)\end{array}$ & 1 & $.560(*)$ & $\begin{array}{l}.619 \\
(* *)\end{array}$ & $\begin{array}{l}.703 \\
(* *)\end{array}$ \\
\hline Sig. & .003 & . & .016 & .006 & .001 \\
\hline $\begin{array}{l}\mathrm{N} \\
\text { the }\end{array}$ & 18 & 18 & 18 & 18 & 18 \\
\hline $\begin{array}{l}\text { proportion of } \\
\text { labors in } \\
\text { primary } \\
\text { industry }\end{array}$ & $\begin{array}{c}-.896 \\
(* *)\end{array}$ & $\begin{array}{c}-.560 \\
(*)\end{array}$ & 1 & $\begin{array}{c}-.954 \\
(* *)\end{array}$ & $\begin{array}{c}-.753 \\
(* *)\end{array}$ \\
\hline Sig. & .000 & .016 & . & .000 & .000 \\
\hline $\mathrm{N}$ & 18 & 18 & 18 & 18 & 18 \\
\hline $\begin{array}{c}\text { average } \\
\text { machinery } \\
\text { gross power }\end{array}$ & $\begin{array}{l}.977 \\
(* *)\end{array}$ & $\begin{array}{l}619 \\
(* *)\end{array}$ & $\begin{array}{c}-.954 \\
(* *)\end{array}$ & 1 & $\begin{array}{l}.845 \\
(* *)\end{array}$ \\
\hline Sig. & .000 & .006 & .000 & . & .000 \\
\hline $\mathrm{N}$ & 18 & 18 & 18 & 18 & 18 \\
\hline $\begin{array}{l}\text { average } \\
\text { amount of } \\
\text { chemical } \\
\text { fertilizer }\end{array}$ & $\begin{array}{l}.845 \\
(* *)\end{array}$ & $\begin{array}{l}.703 \\
(* *)\end{array}$ & $\begin{array}{c}-.753 \\
(* *)\end{array}$ & $\begin{array}{l}.845 \\
(* *)\end{array}$ & 1 \\
\hline Sig. & .000 & .001 & .000 & .000 & . \\
\hline $\mathrm{N}$ & 18 & 18 & 18 & 18 & 18 \\
\hline
\end{tabular}

** Correlation is significant at the 0.01 level (2-tailed).

* Correlation is significant at the 0.05 level (2-tailed). 


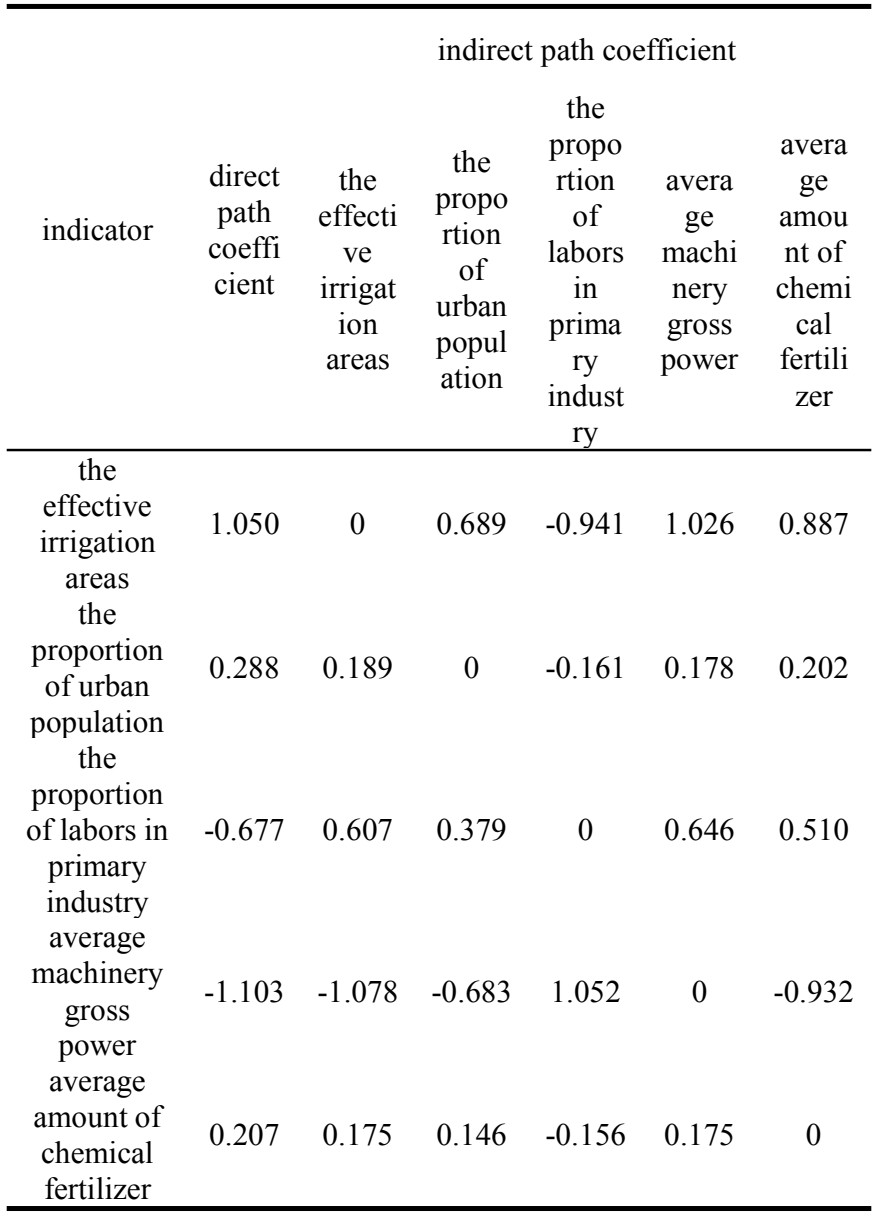

\section{CONCLUSIONS}

Through model analysis, we can see that the main factors of influencing per capita household operating income are $\mathrm{X}_{6}$ the effective irrigation areas, $\mathrm{X}_{11}$ the proportion of urban population, $\mathrm{X}_{12}$ the proportion of labors in primary industry, $\mathrm{X}_{5}$ average machinery gross power and $\mathrm{X}_{4}$ average amount of chemical fertilizer.

(1) The effective irrigation area is an infrastructure factor. As a basic factor, it is the most significant factor in influencing household operating income in Heilongjiang ${ }^{[9]}$.

(2) The proportion of urban population is an urbanization factor. It is a main indicator to describe the urbanization rate. The increase of urban population represents the strengthening of urbanization which plays a relatively remarkable role in influencing household operating income. Also, the proportion of urban population plays an indirect role in it.

(3) The proportion of rural labors in primary industry is a labor transfer factor. It is the main factor to measure the transferring of rural labors and its changing direction is opposite to household operating income. Through the linear regression model, when the proportion of rural labors in primary industry increases a unit (one percentage point), per capita household operating income will decrease 91.210 yuan. The direct correlation coefficient between them is 0.677 and the indirect correlation coefficient is 0.206 between them. This indicates that the proportion of rural labors in primary industry has a direct impact on household operating income ${ }^{[10]}$.

(4) The average machinery gross power is a mechanization factor. It is the main factor of mechanization. Using the linear regression model, it is opposite to household operating income. When average machinery gross power increases a unit (per capita increasing one kilowatt power), per capita household operating income will decrease 2004.043 yuan.

(5) The amount of chemical fertilizer is a technological factor. It is one of the main factors in scientific and technological factors which have an obvious positive impact on farmers' household operating income.

\section{ACKNOWLEDGMENT}

The paper is funded by the following items. $\mathrm{PhD}$ Research Project Started of Harbin University of Commerce (14rw10). This paper is the phase progress of Philosophy and Social Science Project of Heilongjiang Province "Policy Combination and Supporting Measures of Rural Land Transfer ( item number 14B115 ) ". This paper is supported by Science Research Foundation of Northeast Agricultural University (item number 2012RCB77).

\section{REFERENCES}

[1] Patton M. P, Kostov, S, McErlean, and J Moss. Assessing The Influence of Direct Payments On The Rental Value Of Agricultural Land [J]. Food Policy, 2008, Vol. 33 (5): 397-405.

[2] Kirwan, B. The Incidence of U.S. Agricultural Subsidies on Farmland Rental Rates [J]. Journal of Political Economy, 2009 (117): 138-164.

[3] Zhang Dehua, Zhou Huiqiu and Lou Sha. The problems and the countermeasures in food production in Heilongjiang [J]. Research of Agricultural Modernization. 2012(4):411-414.

[4] Lou Sha, Liu Huiping, Zhang Dehua. Comparative study on grain production and farmers' income coordination in Heilongjiang [J] Research of Agricultural Modernization. 2013, Vol.34 (6):654-658.

[5] Patton M. P, Kostov, S, McErlean, and J Moss. Assessing The Influence of Direct Payments On The Rental Value Of Agricultural Land [J]. Food Policy. 2008, Vol. 33(5): 397-405.

[6] Zhou Qiren. Property and Institutional Change [M]. Beijing University Press, 2004.

[7] Zhang Dehua. Study on influential factors and countermeasures of farmers' income in Heilongjiang [M]. Harbin: Northeast Agricultural University, 2013.

[8] Chen Yin'e, Xing Naiqian, Shi Wenming, Impact of rura infrastructure investment on farmers' income - An empirical study based on dynamic panel data model [J] Journal of Zhongnan University of Economics and Law, 2012 (1): 97- 102

[9] Fang Junxiong, Empirical research for expenditure impacting on farmers' income [J], Economic Research, 2012 (10): 42

[10] Cao Yukun, Chen Jiancheng, Chen Lirong. Game analysis on subject behaviors and policies in state-owned forest tenure reform in Yichun [J]. Issues in Agricultural Economy, 2010(5):89-95. 